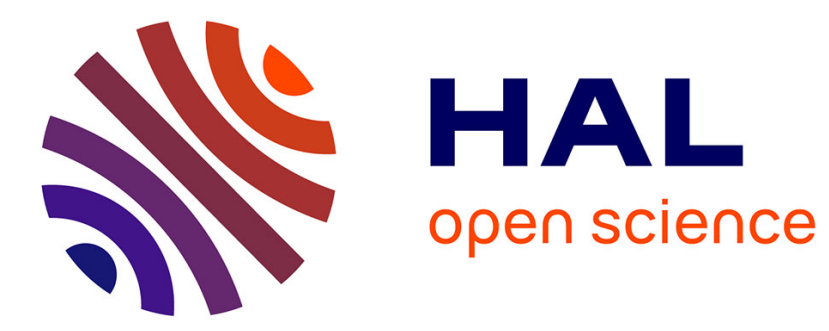

\title{
Eyes wide shut: literacy, phonology and adaptive resonance
}

\author{
Johannes C Ziegler
}

\section{To cite this version:}

Johannes C Ziegler. Eyes wide shut: literacy, phonology and adaptive resonance. Annee Psychologique, 2018, 118 (4), pp.397-402. hal-02171818

\section{HAL Id: hal-02171818 https://hal-amu.archives-ouvertes.fr/hal-02171818}

Submitted on 3 Jul 2019

HAL is a multi-disciplinary open access archive for the deposit and dissemination of scientific research documents, whether they are published or not. The documents may come from teaching and research institutions in France or abroad, or from public or private research centers.
L'archive ouverte pluridisciplinaire HAL, est destinée au dépôt et à la diffusion de documents scientifiques de niveau recherche, publiés ou non, émanant des établissements d'enseignement et de recherche français ou étrangers, des laboratoires publics ou privés. 


\section{EYES WIDE SHUT: LITERACY, PHONOLOGY AND ADAPTIVE RESONANCE}

Johannes C. Ziegler

Presses Universitaires de France | « L'Année psychologique »

2018/4 Vol. 118 | pages 397 à 402

ISSN 0003-5033

ISBN 9782130803560

Article disponible en ligne à l'adresse :

https://www.cairn.info/revue-l-annee-psychologique-2018-4-page-397.htm

Distribution électronique Cairn.info pour Presses Universitaires de France.

(C) Presses Universitaires de France. Tous droits réservés pour tous pays.

La reproduction ou représentation de cet article, notamment par photocopie, n'est autorisée que dans les limites des conditions générales d'utilisation du site ou, le cas échéant, des conditions générales de la licence souscrite par votre établissement. Toute autre reproduction ou représentation, en tout ou partie, sous quelque forme et de quelque manière que ce soit, est interdite sauf accord préalable et écrit de l'éditeur, en dehors des cas prévus par la législation en vigueur en France. Il est précisé que son stockage dans une base de données est également interdit. 


\title{
Eyes wide shut: literacy, phonology and adaptive resonance
}

\author{
Johannes C. Ziegler ${ }^{1^{*}}$ \\ ${ }^{1}$ Aix Marseille Université, CNRS, Laboratoire de Psychologie Cognitive
}

\begin{abstract}
In the present article, I question the claim that a literacy bias is responsible for the fact that major theoreticians underestimated or ignored the role of literacy in spoken language. Instead, I argue that the strongly modular, localist and symbolic information-processing approach to cognition that has dominated psychological science throughout the $20^{\text {th }}$ century has prevented cross-fertilization and the emergence of a unified theory of written and spoken language processing. I show that the recognition of the fundamental role of phonology in reading had suffered from exactly the same "bias", which had eventually been overcome not by breaking the "literacy glasses" but by shifting theoretical frameworks. I conclude by arguing that a marriage between cognitive science, evolutionary biology and neuroscience is needed more than ever to develop a unified, developmentally, biologically and evolutionary plausible theory of written and spoken language.
\end{abstract}

\section{Les yeux grands fermés : littératie, phonologie et résonance adaptative}

\section{RÉSUMÉ}

Dans le présent article, je remets en question l'idée selon laquelle un «biais de littératie " est responsable du fait que les principaux théoriciens ont sous-estimé ou ignoré le rôle de la littératie dans l'étude du langage oral. Je développe l'hypothèse selon laquelle l'approche modulaire, localiste et symbolique du traitement de l'information qui a dominé les sciences psychologiques tout au long du $\mathrm{XX}^{\mathrm{e}}$ siècle a empêché l'émergence d'une théorie unifiée du traitement du langage écrit et parlé. Je montre que le même «biais » explique pourquoi il fallait des dizaines d'années pour reconnaître le rôle fondamental du traitement phonologique lors de la lecture. Je conclus en affirmant qu'un mariage entre les sciences cognitives,

\footnotetext{
${ }^{* 1}$ Aix Marseille Université, CNRS, Laboratoire de Psychologie Cognitive (UMR 7290), 3 Place Victor Hugo, 13003 Marseille, France. E-mail: Johannes.ziegler@univ-amu.fr
} 
la biologie évolutive et les neurosciences est plus que jamais nécessaire pour développer une théorie unifiée du langage écrit et parlé plausible sur le plan développemental et biologique.

In their target article, Kolinsky and Morais (2019) elegantly demonstrate that most scholars in the fields of language, linguistics and cognition underestimate or fully ignore the impact of literacy on language processing despite the large number of inventive experimental demonstrations using a variety of paradigms, measures and languages which show the opposite (e.g., Pattamadilok, Morais, Colin, \& Kolinsky, 2014; Perre, Midgley, \& Ziegler, 2009; Salverda and Tanenhaus, 2010; Ventura, Morais, Pattamadilok, \& Kolinsky, 2004; Ziegler, Petrova, \& Ferrand, 2008; Zou, Desroches, Liu, Xia, \& Shu, 2012). These findings have converged to suggest that literacy strongly affects the way our brains process spoken language (Dehaene, Cohen, Morais, \& Kolinsky, 2015; Dehaene et al., 2010; Montant, Schön, Anton, \& Ziegler, 2011; Pattamadilok, Knierim, Kawabata Duncan, \& Devlin, 2010; Pattamadilok, Perre, Dufau, \& Ziegler, 2009; Perre, Pattamadilok, Montant, \& Ziegler, 2009; Taft, Castles, Davis, Lazendic, \& Nguyen-Hoan, 2008). In fact, these results had been anticipated many years before in an editorial in Brain entitled "Literally changing the brain", in which Uta Frith (1998) stated that "the acquisition of an alphabetic code is like catching a virus... this virus infects all speech processing... Language is never the same again" (p. 1051). However, contrary to the Kolinsky and Morais, I do not think that wearing "literate glasses" is responsible for the fact that major theoreticians ignored the role of literacy in spoken language. I also do not think that the "double marriage of cognitive science with evolutionary biology and neuroscience, on the one hand, and informatics and computational sciences, on the other hand" (p. 6) can be blamed for the situation. Instead, I believe that the strongly modular, localist, and symbolic information-processing approach to cognition that has dominated psychological science throughout the $20^{\text {th }}$ century has prevented cross-fertilization and the emergence of a unified theory of written and spoken language processing.

Let us go back in time to make this point more clearly. Before thinking about a potential role of orthography in spoken language, one had to recognize that spoken language (i.e., phonology) played an essential role in reading, a tough row to hoe back in the 90s (e.g., Van Orden, 1987; Van Orden, Johnston, \& Hale, 1988). Was it because we were wearing literate glasses that it took the field more than 20 years to recognize the 
role of phonology in visual word recognition? A look across the street to developmental psychology and theories of reading development would have been sufficient to appreciate its fundamental role in learning-to-read (Goswami and Bryant, 1990; Share, 1995). Yet, the dominant theories of visual word recognition remained "stubbornly nonphonological" (Carello, Turvey, \& Lukatela, 1992) for many years. Ziegler and Goswami (2005) suggested that such reluctance was possibly due to the fact that "cognitive psychology and developmental psychology have often been uncomfortable bedfellows" (p. 21) but we now believe that it was the modular theoretical framework that favored Occam's razor (Jacobs and Grainger, 1994) over biological and developmental plausibility (Goswami and Ziegler, 2006). How could we have thought for one second that the way children learn to read - through phonological decoding and access to spoken language representations (Ziegler, Perry, \& Zorzi, 2014) - would only be a transient process to be rapidly replaced by an autonomous encapsulated module that makes sense of letter strings without reference to phonology? The death blow came from brain imaging, which, ironically, had often been used as a search light for finding isolated modules rather than interactive systems. Yet, a large number of brain imaging studies showed that learning-to-read merely added an orthographic interface to the spoken language system, a new pathway that connects an ancient neural systems that deals with visual features (lines, angles, intersections) with yet another ancient system that is in charge of spoken language. As it turned out, written words activate the entire spoken language system (with the exception of a small region around the auditory cortex) and this is true for both alphabetic and nonalphabetic writing systems (Rueckl et al., 2015).

The framework that predicted such strong phonological effects was the resonance theory of word perception (Stone and Van Orden, 1994; Van Orden and Goldinger, 1994), which argued that word perception is made possible through a dynamic bidirectional coupling between orthography, phonology and semantics. The coupling was thought to be stronger between orthography and phonology than between orthography and semantics because of the systematic relations between letters and sounds (e.g., knowing that a word starts with the letter $\mathrm{T}$ tells us nothing about is meaning but all about its sound). Interestingly, it was not our awareness of wearing literate glasses but the key idea of a bidirectional coupling (i.e., resonance) between orthography and phonology that motivated Ziegler and Ferrand (1998) to look for orthographic consistency effects in spoken language, which have since been replicated in many languages and paradigms using a variety of methods (mouse tracking, eye movements, EEG, TMS, fMRI). While many of us initially thought that these effects would 
only occur at a meta-phonological level (Morais, Cary, Alegria, \& Bertelson, 1979) or in laboratory tasks that presented spoken words in isolation, subsequent research has clearly established that literacy effects on spoken language can be observed when people listen to spoken sentences (Dehaene et al., 2010) or in nonlexical tasks (Perre, Bertrand, \& Ziegler, 2011). They are automatic (Taft et al., 2008), pre-attentive (Pattamadilok et al., 2014) and affect even very basic auditory processes at the level of the neural representations of phonemes in the auditory cortex (Dehaene et al., 2010). We see this as a small but significant demonstration that "changing glasses" can sometimes improve scientific vision.

While resonance theory focused much on the statistical properties of associations between form and function, the theory remained somewhat detached from the neurobiological, developmental and evolutionary aspects of how words and their meanings might be represented in the brain (Pulvermuller, 1999). That is, children come to the task of learning to read with an almost fully developed spoken language system, in which spoken words are associated with their meanings. Thus, it is a developmentally and evolutionary optimal strategy to connect the visual word form system to the primary spoken language system regardless of whether or not there is a tight mapping of letters onto sounds. Thus, the reading network is not created from scratch but its development relies heavily on the re-use of the spoken language network (Goswami and Ziegler, 2006; Ziegler and Goswami, 2005). Neural reuse is indeed a fundamental developmental and evolutionary strategy for realizing cognitive functions (see Grasso \& Montant, 2019, this issue). Together then, the time seems ripe for developmentally, biologically and evolutionary plausible theories that go beyond modules (Van Orden and Kloos, 2003). More than ever, a marriage between cognitive science, evolutionary biology and neuroscience is needed to make further progress.

\section{REFERENCES}

Carello, C., Turvey, M. T., \& Lukatela, G. (1992). Can theories of word recognition remain stubbornly nonphonological? In R. Frost \& L. Katz (Eds.), Orthography, Phonology, Morphology, and Meaning. Advan- ces in Psychology, Vol. 94 (pp. 211-226). Oxford, England: North-Holland.

Dehaene, S., Cohen, L., Morais, J., \& Kolinsky, R. (2015). Illiterate to literate: behavioural and cerebral changes induced 
by reading acquisition. Nat. Rev. Neurosci., 16(4), 234-244.

Dehaene, S., Pegado, F., Braga, L. W., Ventura, P., Nunes Filho, G., Jobert, A., .. . Cohen, L. (2010). How learning to read changes the cortical networks for vision and language. Science, 330(6009), 13591364.

Frith, U. (1998). Editorial: Literally changing the brain. Brain, 121, 1051-1052.

Goswami, U., \& Bryant, P. (1990). Phonological Skills and Learning to Read: Hillsdale, NJ, England: Lawrence Erlbaum Associates, Inc.

Goswami, U., \& Ziegler, J. C. (2006). A developmental perspective on the neural code for written words. Trends Cogn. Sci., 10(4), 142-143.

Grasso, C., \& Montant, M. (2019). Bodyblindness in langage studies. L'Année psychologique/Topics in Cognitive Psychology.

Jacobs, A. M., \& Grainger, J. (1994). Models of visual word recognition: Sampling the state of the art. Journal of Experimental Psychology: Human Perception \& Performance, 20(6), 1311-1334.

Kolinsky, R. \& Morais, J. (2019). The worries of wearing literate glasses, L'Année psychologique/Topics in Cognitive Psychology.

Montant, M., Schön, D., Anton, J.-L., \& Ziegler, J. C. (2011). Orthographic contamination of Broca's area. Frontiers in Psychology, 2, 10.3389/fpsyg.2011.00378.

Morais, J., Cary, L., Alegria, J., \& Bertelson, P. (1979). Does awareness of speech as a sequence of phones arise spontaneously? Cognition, 7(4), 323-331.

Pattamadilok, C., Knierim, I. N., Kawabata Duncan, K. J., \& Devlin, J. T. (2010). How does learning to read affect speech perception? J. Neurosci., 30(25), 8435-8444.

Pattamadilok, C., Morais, J., Colin, C., \& Kolinsky, R. (2014). Unattentive speech processing is influenced by orthographic knowledge: evidence from mismatch negativity. Brain Lang, 137, 103-111.

Pattamadilok, C., Perre, L., Dufau, S., \& Ziegler, J. C. (2009). On-line Orthographic Influences on Spoken Language in a Semantic Task. Journal of Cognitive Neuroscience, 21(1), 169-179.

Perre, L., Bertrand, D., \& Ziegler, J. C. (2011). Literacy affects spoken language in a non-linguistic task: An ERP study. Frontiers in Psychology, 2, 1-8.

Perre, L., Midgley, K., \& Ziegler, J. C. (2009). When beef primes reef more than leaf: Orthographic information affects phonological priming in spoken word recognition. Psychophysiology, 46(4), 739-746.

Perre, L., Pattamadilok, C., Montant, M., \& Ziegler, J. C. (2009). Orthographic effects in spoken language: On-line activation or phonological restructuring? Brain Research, 1275, 73-80.

Pulvermuller, F. (1999). Words in the brain's language. Behav. Brain Sci., 22(2), 253-279; discussion 280-336.

Rueckl, J. G., Paz-Alonso, P. M., Molfese, P. J., Kuo, W. J., Bick, A., Frost, S. J., . . . Frost, R. (2015). Universal brain signature of proficient reading: Evidence from four contrasting languages. Proc. Natl. Acad. Sci. U S A, 112(50), 15510-15515.

Salverda, A. P., \& Tanenhaus, M. K. (2010). Tracking the time course of orthographic information in spoken-word recognition. J. Exp .Psychol. Learn Mem. Cogn., 36(5), 1108-1117.

Share, D. L. (1995). Phonological recoding and self-teaching: Sine qua non of reading acquisition. Cognition, 55(2), 151-218.

Stone, G. O., \& Van Orden, G. C. (1994). Building a resonance framework for word recognition using design and system principles. Journal of Experimental Psychology: Human Perception \& Performance, 20(6), 1248-1268.

Taft, M., Castles, A., Davis, C., Lazendic, G., \& Nguyen-Hoan, M. (2008). Automatic 
activation of orthography in spoken word recognition: Pseudohomograph priming. Journal of Memory \& Language, 58, 366379.

Van Orden, G. C. (1987). A ROWS is a ROSE: Spelling, sound, and reading. Memory \& Cognition, 15(3), 181-198.

Van Orden, G. C., \& Goldinger, S. D. (1994). Interdependence of form and function in cognitive systems explains perception of printed words. Journal of Experimental Psychology: Human Perception \& Performance, 20(6), 1269-1291.

Van Orden, G. C., Johnston, J. C., \& Hale, B. L. (1988). Word identification in reading proceeds from spelling to sound to meaning. Journal of Experimental Psychology: Learning, Memory, \& Cognition, 14(3), 371-386.

Van Orden, G. C., \& Kloos, H. (2003). The module mistake. Cortex, 39(1), 164-166.

Ventura, P., Morais, J., Pattamadilok, C., \& Kolinsky, R. (2004). The locus of the orthographic consistency effect in auditory word recognition. Language and Cognitive Processes, 19(1), 57-95.

Ziegler, J. C., \& Ferrand, L. (1998). Orthography shapes the perception of speech: The consistency effect in auditory word recognition. Psychonomic Bulletin \& Review, 5(4), 683-689.

Ziegler, J. C., \& Goswami, U. (2005). Reading acquisition, developmental dyslexia, and skilled reading across languages: a psycholinguistic grain size theory. Psychological Bulletin, 131(1), 3-29.

Ziegler, J. C., Perry, C., \& Zorzi, M. (2014). Modelling reading development through phonological decoding and self-teaching: implications for dyslexia. Philosophical Transactions of the Royal Society B: Biological Sciences, 369(1634).

Ziegler, J. C., Petrova, A., \& Ferrand, L. (2008). Feedback consistency effects in visual and auditory word recognition: where do we stand after more than a decade? Journal of Experimental Psychology: Learning Memory \& Cognition, 34(3), 643661.

Zou, L., Desroches, A. S., Liu, Y., Xia, Z., \& Shu, H. (2012). Orthographic facilitation in Chinese spoken word recognition: an ERP study. Brain Lang, 123(3), 164-173. 